\title{
SKRINING DAN IDENTIFIKASI BAKTERI ANTI QUORUM SENSING ASAL TAMBAK UDANG VANAME PENGHAMBAT VIRULENSI Vibrio parahaemolyticus
}

\author{
Emei Widiyastuti ${ }^{* * \#}$, Iman Rusmana*), dan Munti Yuhana**) \\ *) Balai Uji Standar Karantina Ikan Pengendalian Mutu dan Keamanan Hasil Perikanan \\ Jalan Raya Setu No. 1, Setu Cipayung, RT.3/RW.3, Setu, Jakarta Timur 13880 \\ *) Institut Pertanian Bogor \\ Kampus IPB, JI. Raya Dramaga, Babakan, Kec. Dramaga, Kota Bogor, Jawa Barat 16680
}

(Naskah diterima: 6 Agustus 2020; Revisi final: 15 Desember 2020; Disetujui publikasi: 18 Desember 2020)

\begin{abstract}
ABSTRAK
Vibriosis dapat dicegah dan dikendalikan dengan memanfaatkan mekanisme anti quorum sensing (AQS). Salah satu strategi anti quorum sensing dalam menghambat ekspresi faktor virulen dari Vibrio parahaemolyticus yaitu dengan mendegradasi sinyal komunikasi sel bakteri menggunakan AHL laktonase. Penelitian ini bertujuan untuk menyeleksi dan mengindentifikasi bakteri penghasil AHL laktonase yang berpotensi mampu menghambat virulensi bakteri patogen V. parahaemolyticus. Isolasi bakteri dilakukan dari sampel saluran pencernaan udang vaname, air, dan sedimen tambak. Sebanyak 18 dari 111 isolat yang diisolasi menunjukkan adanya aktivitas AQS terhadap bioindikator Chromobacterium violaceum. Hasil uji patogenitas secara in vitro pada agar darah didapatkan tiga isolat yang tidak menunjukkan aktivitas hemolisis yaitu B5, K4, dan S12. Hasil konfirmasi dan analisis gen aiiA menggunakan Blast-X menunjukkan bahwa isolat B5 dan S12 memiliki kesamaan dengan AHL laktonase pada Bacillus cereus, sedangkan K4 memiliki similaritas dengan AHL laktonase pada multispesies Bacillus sp. Hasil pensejajaran sekuen gen 16S rRNA ketiga isolat tersebut dengan data pada GenBank, teridentifikasi sebagai Bacillus siamensis (B5), Bacillus cereus (K4), dan Bacillus amyloliquefaciens (S12). Berdasarkan hasil uji antagonis dan uji kultur bersama disimpulkan bahwa isolat K4 bekerja dengan mekanisme AQS sedangkan isolat B5 dan S12 diduga berjalan dua mekanisme secara bersama yaitu antibiosis dan anti quorum sensing. Hasil penelitian ini menunjukkan bahwa ketiga isolat tersebut memiliki potensi sebagai kandidat agen biokontrol pada akuakultur sehingga perlu dilakukan uji lanjutan.
\end{abstract}

KATA KUNCl: Vibrio parahaemolyticus; anti quorum sensing (AQS); AHL-laktonase

ABSTRACT: Screening and identification of anti-quorum sensing bacteria from vannamei shrimp ponds as virulence inhibitors of Vibrio parahaemolyticus. By: Emei Widiyastuti, Iman Rusmana, and Munti Yuhana

Vibriosis can be prevented and controlled by utilizing the anti-quorum sensing (AQS) mechanism. One of the anti-quorum sensing mechanisms to inhibit the expression of virulent factors of Vibrio parahaemolyticus is by degrading the quorum sensing communication signals using AHL lactonase. The study aimed to select and identify AHL lactonase-producing bacteria that have the potentials to inhibit the virulence of V. parahaemolyticus. Several batches of bacteria were isolated from the digestive tract of vannamei shrimp, water, and sediment of shrimp ponds. There were 18 out of 111 isolates that showed AQS activity against Chromobacterium violaceum used as a bioindicator. In vitro pathogenicity test on blood agar showed that $\mathrm{B} 5, \mathrm{~K} 4$, and $\mathrm{S} 12$ isolates showed gamma hemolysis activity. The results of confirmation and analysis of aiiA genes using Blast-X showed that B5 and S12 isolates have AHL lactonase similarities with Bacillus cereus, whereas K4 has similarities with multispecies Bacillus sp. Alignment results of the 165 rRNA gene sequences with GenBank data showed that B5, K4, and S12 isolates were identified as Bacillus siamensis, Bacillus cereus, and Bacillus amyloliquefaciens, respectively. The follow up antagonistic and coculture tests revealed that K4 uses the AQS mechanism, while B5 and S12 likely use antibiotic mechanism

\footnotetext{
\# Korespondensi: Balai Uji Standar Karantina Ikan Pengendalian Mutu dan Keamanan Hasil Perikanan. Jalan Raya Setu No. 1, Setu Cipayung, RT.3/RW.3, Setu, Jakarta Timur 13880, Indonesia Tel. + 62218448506

E-mail: emei.widiyastuti@gmail.com
} 
and anti quorum sensing to inhibit the virulent expression of $\mathbf{V}$. parahaemolyticus. This study concludes that the three isolates have the potential to be used as biocontrol agents in brackishwater aquaculture. Further research is needed to determine the pathogenicity of AQS bacteria to vannamei shrimp and the effective concentration of AQS bacteria to inhibit the virulence of $\mathbf{V}$. parahaemolyticus to vannamei shrimp by in vivo treatment.

\section{KEYWORDS: Vibrio parahaemolyticus; anti-quorum sensing (AQS); AHL-lactonase}

\section{PENDAHULUAN}

Vibriosis pada budidaya udang vaname merupakan salah satu kendala yang sering dihadapi para petambak, salah satunya disebabkan oleh bakteri Vibrio parahaemolyticus (Sarjito et al., 2018). Vibrio parahaemolyticus strain tertentu dilaporkan juga sebagai salah satu jenis bakteri pembawa toksin agen penyebab Acute hepatopancreatic necrosis disease (AHPND) pada udang vaname (Tran et al., 2013). Petambak selama ini sering menggunakan antibiotik secara berlebihan dan tidak tepat sasaran untuk mengendalikan vibriosis, sehingga memicu terjadinya resistensi antibiotik, serta efek residu pada biota perairan.

Terdapat alternatif pencegahan dan pengendalian vibriosis yang ramah lingkungan, salah satunya adalah dengan menghambat ekspresi gen faktor virulen dari V. parahaemolyticus. Regulasi gen virulen merupakan salah satu respons positif dari mekanisme quorum sensing (Defoirdt et al., 2004). Mekanisme ini berjalan jika kelimpahan sinyal komunikasi antar sel atau auto induser di lingkungan mencapai quorum. Senyawa autoinduser yang dihasilkan oleh V. parahaemolyticus berupa acyl homoserin lactones (AHL) yaitu 3-0xo-C6HSL (Vinoj et al., 2014). Apabila quorum sensing dari populasi V. parahaemolyticus di lingkungan terganggu, maka dapat menghambat virulensi bakteri. Gangguan tersebut salah satunya dapat berupa terdegradasinya senyawa autoinduser oleh enzim laktonase sehingga kondisi quorum AHL tidak tercapai. Selanjutnya tidak terjadi respons balik yang diterima oleh reseptor sel bakteri dan pada akhirnya regulasi faktor virulen pun tidak terjadi. Enzim ini juga dapat dihasilkan oleh bakteri yang dikenal dengan bakteri anti quorum sensing (AQS).

Penelitian mengenai pengaplikasian bakteri AQS untuk menangani vibriosis pun telah dilakukan dan menunjukkan hasil yang memuaskan di antaranya adalah $B$. subtilis berhasil menghambat virulensi V. harveyi pada larva Penaeus monodon (Yuniarti et al., 2015); selain itu, B. licheniformis mampu mengurangi kematian larva vaname yang dinfeksi V. parahemolyticus (Vinoj et al., 2014). Melihat adanya potensi bakteri $\mathrm{AQS}$ asal tambak udang vaname untuk mencegah vibriosis, maka dilakukan penelitian ini yang bertujuan untuk menyeleksi dan mengindentifikasi bakteri penghasil AHL laktonase yang berpotensi mampu menghambat virulensi V. parahaemolyticus.

\section{BAHAN DAN METODE}

\section{Bahan Uji}

V. parahaemolyticus koleksi Balai Uji Standar Karantina Ikan Pengendalian Mutu (BUSKIPM) Kementerian Kelautan dan Perikanan. Chromobacterium violaceum (Cv) koleksi Laboratorium Mikrobiologi Fakultas Kedokteran, Universitas Indonesia.

\section{Isolasi Bakteri AQS Pendegradasi AHL}

Sebanyak satu gram sampel (organ pencernaan, sedimen dan $1 \mathrm{~mL}$ air tambak) dihomogenasi lalu dipanaskan pada suhu $80^{\circ} \mathrm{C}$ selama 15 menit selanjutnya dilakukan pengenceran berseri hingga $10^{10}$. Sebanyak $0,1 \mathrm{~mL}$ suspensi disebar pada media isolasi bakteri laut yaitu seawater complate agar atau SWC $50 \%$ (air laut $750 \mathrm{~mL}$; akuades $250 \mathrm{~mL}$; bakto pepton 2,5 g; bakto agar $20 \mathrm{~g}$; yeast ekstrak 0,5 g; dan gliserol $1,5 \mathrm{~mL}$ ) secara duplo kemudian diinkubasi 24 sampai 48 jam pada suhu $30^{\circ} \mathrm{C}$ dalam kondisi aerob (Umoro, 2016). Koloni bakteri yang memiliki morfologi (ukuran, warna, dan bentuk) berbeda kemudian dimurnikan dengan metode gores kuadran hingga didapat koloni tunggal dan seragam.

\section{Seleksi Bakteri AQS dengan Bioesei Terhadap C. violaceum}

Seleksi bakteri AQS menggunakan bioindikator $\mathrm{C}$. violaceum dengan metode disc diffusion. Isolat bakteri ditumbuhkan pada SW C broth dengan di-shaker selama 24-72 jam. Kultur disentrifugasi pada 11.000 rpm selama 10 menit. Sebanyak $100 \mu \mathrm{L}$ filtrat supernatan diteteskan di atas paper disk steril $(6 \mathrm{~mm})$ pada permukaan media semi padat Luria-Bertani agar (LA) $1,2 \%$ yang mengandung kultur $1 \% \mathrm{C}$. violaceum $10^{9}$ $\mathrm{CFU} / \mathrm{mL}(\mathrm{v} / \mathrm{v})$, lalu diinkubasi pada suhu $28^{\circ} \mathrm{C}$ selama 24 jam. C. violaceum $1 \%$ ditanam pada media semi padat LA dengan metode agar tuang. Kontrol negatif menggunakan SWC broth steril. Aktivitas degradasi AHL ditunjukkan dengan terbentuknya zona tidak berwarna ungu di sekitar paper disk. Indeks degradasi (ID) AHL menggunakan rumus sebagai berikut: 


$$
\text { ID } A H L=\frac{d \text { zona tidak ungu }- \text { d paper disk }}{\text { d paper disk }} \times 100 \%
$$

di mana: $d=$ diameter

\section{Pengukuran Unit Violacein pada C. violaceum}

Sebanyak $300 \mu \mathrm{L}$ supernatan bakteri AQS ditambahkan pada $30 \mathrm{~mL}$ medium Luria-Bertani Broth (LB) yang telah diinokulasi dengan $1 \% \mathrm{C}$. violaceum (v/ v). Kultur diinkubasi pada inkubator bergoyang dengan kecepatan $150 \mathrm{rpm}$ pada suhu $28^{\circ} \mathrm{C}$. Ekstrak pigmen violacein diambil dan diukur setelah inkubasi 48 dan 72 jam. Kultur C. violaceum disentrifugasi pada kecepatan $11.000 \mathrm{rpm}$ selama 15 menit, pelet ditambahkan 1,5 mL DMSO, di-vortex kemudian disentrifugasi 11000 rpm selama 15 menit. Violacein terlarut diukur absorbansinya pada panjang gelo mbang $585 \mathrm{~nm}$, pertumbuhan bakteri $\mathrm{C}$. violaceum diukur pada $600 \mathrm{~nm}$. Unit violacein dihitung dari rasio absorbansi $585 \mathrm{~nm}$ dengan absorbansi $600 \mathrm{~nm}$ (Chaudhari et al., 2014). Kontrol negatif yang digunakan hanya kultur C. violaceum tanpa penambahan bakteri uji AQS.

\section{Uji Patogenitas Bakteri AQS Secara In Vitro}

Bakteri uji AQS ditumbuhkan pada media agar darah lalu diinkubasi selama 24 jam pada suhu $30^{\circ} \mathrm{C}$. Isolat dipilih yang tidak menunjukkan aktivitas hemolisis.

\section{Deteksi Gen aiiA Penyandi AHL Laktonase}

DNA genom bakteri AQS yang terpilih diisolasi menggunakan mericon DNA Bacteria Kit Plus (Qiagen). Amplifikasi gen aiiA menggunakan primer aiiAF (5'ATGGGATCCATGACAGTAAAGAAGCTTTAT-3') dan primer aiiAR (5'-GTCGAATTCCTCAACAAGA TACTCCTAATG-3') dengan target produk amplikasi 800 bp (Dong et al., 2002). Komponen reaksi amplifikasi PCR untuk volume $25 \mu \mathrm{L}$ terdiri atas 12,5 $\mu \mathrm{L}$ GoTaq Green Master Mix 2X (Promega, Madison, WI, USA), $1 \mu \mathrm{L}$ primer (10 pmol $\left.\mu \mathrm{L}^{-1}\right)$, template DNA dan nuclease free water (NFW). Profil suhu amplifikasi yaitu pradenaturasi $\left(94^{\circ} \mathrm{C}, 10\right.$ menit); 30 siklus untuk denaturasi $\left(94^{\circ} \mathrm{C}, 30\right.$ detik), annealing $\left(52^{\circ} \mathrm{C}\right.$, 30 detik) dan elongasi $\left(72^{\circ} \mathrm{C}\right.$, satu menit); post elongasi $\left(72^{\circ} \mathrm{C}\right.$, lima menit). Produk PCR dipurifikasi menggunakan QIAquick PCR Purification Kit (Qiagen), Ialu disekuensing menggunakan DNA Sequencer $A B I 3130$. Sekuen nukelotida disejajarkan dengan database sekuen pada NCBI menggunakan program Basic Local Aligment Search Tool-Protein (BLAST-X). Analisis filogenetik menggunakan program MEGA $X$ dengan metode Maximum Likelihood dengan bootstrap $1.000 \mathrm{x}$.

\section{Identifikasi Bakteri AQS Berdasarkan Gen Penyandi 16S rRNA}

Amplifikasi gen penyandi 16S rRNA menggunakan primer forward 63F (5'-CAGGCCTAACACATGCAAGTC3') dan primer reverse 1387R (5'GGGCGGWGTGTACAAGGC-3') (Marchesi et al., 1998). Profil suhu amplifikasi, pradenaturasi $\left(95^{\circ} \mathrm{C}\right.$, lima menit); 30 kali siklus untuk denaturasi $\left(95^{\circ} \mathrm{C}\right.$, satu menit), annealing $\left(55^{\circ} \mathrm{C}\right.$, satu menit), elongasi $\left(72^{\circ} \mathrm{C}\right.$, 1,5 menit); post elongasi $\left(72^{\circ} \mathrm{C}, 10\right.$ menit). Visualisasi produk PCR dielektroforesis pada agarose 1\% menghasilkan $1.300 \mathrm{bp}$.

\section{Uji Antagonis dan Kultur Bersama AQS dan V. parahaemolyticus}

Bakteri AQS diinokulasi pada SWC agar yang telah disebar $100 \mu \mathrm{L}$ biakan bakteri V. parahaemolyticus $10^{6}$ $\mathrm{CFU} \mathrm{mL}{ }^{-1}$, diinkubasi pada suhu $30^{\circ} \mathrm{C}$ selama $24-48$ jam, Ialu amati ada tidaknya zona hambat. Uji kultur bersama antara bakteri AQS dan V. parahaemolyticus berdasarkan meto de Gram et al. (1999), masing-masing

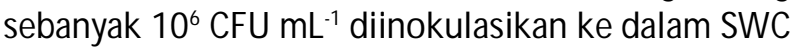
broth, diinkubasi pada $30^{\circ} \mathrm{C}$ selama 24 jam. Kultur disebar pada media TCBS, diinkubasi pada suhu $30^{\circ} \mathrm{C}$ selama 48 jam, Ialu diamati dan dihitung total vibrio count (TVC).

\section{Analisis Data}

Data yang diperoleh dianalisis secara deskriptif.

\section{HASIL DAN BAHASAN}

\section{Isolasi dan Seleksi Bakteri AQS Pendegradasi AHL}

Sebanyak 117 isolat bakteri berhasil diisolasi dari 25 sampel (saluran pencernaan udang, air, dan sedimen tambak). Hasil penapisan menggunakan bakteri bioindikator $\mathrm{C}$. violaceum, 18 isolat di antaranya yang berasal dari sampel sedimen dan saluran pencernaan udang berpotensi memiliki aktivitas degradasi AHL yang ditunjukkan dengan terbentuknya zona tidak ungu di sekitar paper disk yang ditetesi supernatan bakteri uji (Tabel 1 dan Gambar 1). Tidak ditemukan isolat potensial AQS pada sampel air tambak. Zona tidak ungu terbentuk karena adanya hambatan terhadap QS C. violaceum sehingga pigmen violacein tidak diproduksi oleh sel-sel bakteri di sekitar paper disk (McClean et al., 1997). Terganggunya produksi violacein tersebut dapat disebabkan oleh adanya aktivitas enzim laktonase pendegradasi senyawa sinyal acyl homoserine lactone, yang disekresikan dalam supernatan bakteri uji (Novita et al., 2015).

Nilai indeks degradasi AHL yang dihasilkan dari 18 isolat AQS tersebut sangat bervariasi dari 0,33 hingga 
Tabel 1. Sumber dan jumlah isolat hasil isolasi dari saluran pencernaan udang dan lingkungan tambak

Table 1. Source and number of bacterial isolates isolated from shrimp digestive tract and pond environment

\begin{tabular}{|c|c|c|c|c|}
\hline \multicolumn{3}{|c|}{ Sampel (Sample) } & \multirow{2}{*}{$\begin{array}{l}\text { Jumlah isolat } \\
\text { hasil isolasi } \\
\text { Number of } \\
\text { isolates isolated }\end{array}$} & \multirow{2}{*}{$\begin{array}{c}\text { Jumlah dan kode } \\
\text { isolat bakteri AQS } \\
\text { Number and code of } \\
\text { AQS bacterial isolates }\end{array}$} \\
\hline $\begin{array}{c}\text { Asal } \\
\text { Origin }\end{array}$ & $\begin{array}{l}\text { Sumber } \\
\text { Source }\end{array}$ & $\begin{array}{l}\text { Jumlah } \\
\text { Number }\end{array}$ & & \\
\hline \multirow{3}{*}{ Karawang } & $\begin{array}{l}\text { Saluran pencernaan udang } \\
\text { Digestive tract of shrimp }\end{array}$ & 4 & 20 & $3(U 2, U 21)$ \\
\hline & Air (W ater of shrimp pond) & 1 & 3 & \\
\hline & Sedimen (Sediment of shrimp pond) & 1 & 6 & $1(\mathrm{~S} 12)$ \\
\hline \multirow{3}{*}{ Tanggerang } & $\begin{array}{l}\text { Saluran pencernaan udang } \\
\text { Digestive tract of shrimp }\end{array}$ & 2 & 26 & $3(U J 2, U J 5, U J 6)$ \\
\hline & Air (Water of shrimp pond) & 1 & 2 & - \\
\hline & Sedimen (Sediment of shrimp pond ) & 1 & 8 & - \\
\hline \multirow{3}{*}{ Pamanukan } & $\begin{array}{l}\text { Saluran pencernaan udang } \\
\text { Digestive tract of shrimp }\end{array}$ & 4 & 8 & - \\
\hline & Air (Water of shrimp pond) & 2 & 2 & - \\
\hline & Sedimen (Sediment of shrimp pond ) & 3 & 20 & $3(\mathrm{~K} 1, \mathrm{~K} 2, \mathrm{~K} 4)$ \\
\hline \multirow{3}{*}{ Bengkalis } & $\begin{array}{l}\text { Saluran pencernaan udang } \\
\text { Digestive tract of shrimp }\end{array}$ & 2 & 8 & 1 (UB6) \\
\hline & Air (Water of shrimp pond) & 1 & 2 & - \\
\hline & Sedimen (Sediment of shrimp pond ) & 1 & 10 & 5 (M4, M5, M6, M9, M10) \\
\hline \multirow[t]{2}{*}{ Lampung } & Sedimen (Sediment of shrimp pond) & 1 & 2 & $2(\mathrm{~B} 5, \mathrm{~B} 8)$ \\
\hline & Total & 25 & 117 & 18 \\
\hline
\end{tabular}

2, tertinggi dihasilkan oleh isolat S12 dan UB6 sedangkan terendah oleh isolat U21 (Gambar 1 dan 2). Indeks degradasi yang didapat dari supernatan hasil inkubasi 72 jam lebih optimal dibandingkan hasil inkubasi 24 jam. Hal ini diduga lambatnya sekresi enzim ekstraselular pendegradasi AHL pada beberapa isolat bakteri tersebut, seperti yang telah dilaporkan oleh (Tan, 2017). Tren meningkatnya indeks degradasi AHL dari supernatan hasil inkubasi 72 jam, menggambarkan semakin banyaknya enzim pendegradasi AHL yang disekresikan bakteri AQS.
Aktivitas AQS dapat juga ditentukan melalui penambahan supernatan kultur bakteri AQS ke dalam kultur C. violaceum (Suryanti, 2019). Aktivitas AQS ditunjukkan jika supernatan yang diduga mengandung enzim pendegradasi AHL dapat menyebabkan berkurangnya kadar pigmen violacein tanpa memengaruhi pertumbuhan populasi sel bakteri $C$. violaceum. Mekanisme AQS diduga terjadi pada 11 perlakuan di antaranya K4, M4, M5, M9, M10, S12, B5, U34, UJ2, UJ5 dan UJ6 karena terjadi penurunan kadar violacein secara signifikan pada hari ketiga yang
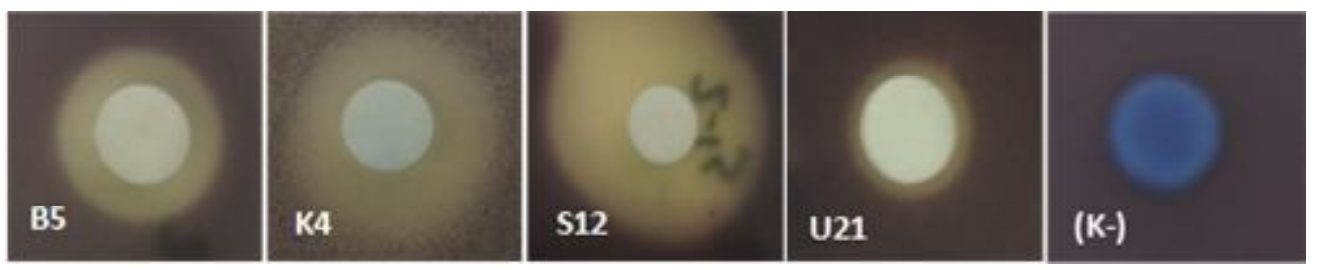

Gambar 1. Aktivitas degradasi AHL isolat bakteri uji terhadap C. violaceum sebagai bioindikator AQS.

Figure 1. AHL degradation activity of selected bacterial isolates against $\mathbf{C}$. violaceum as AQS bioindicator. 


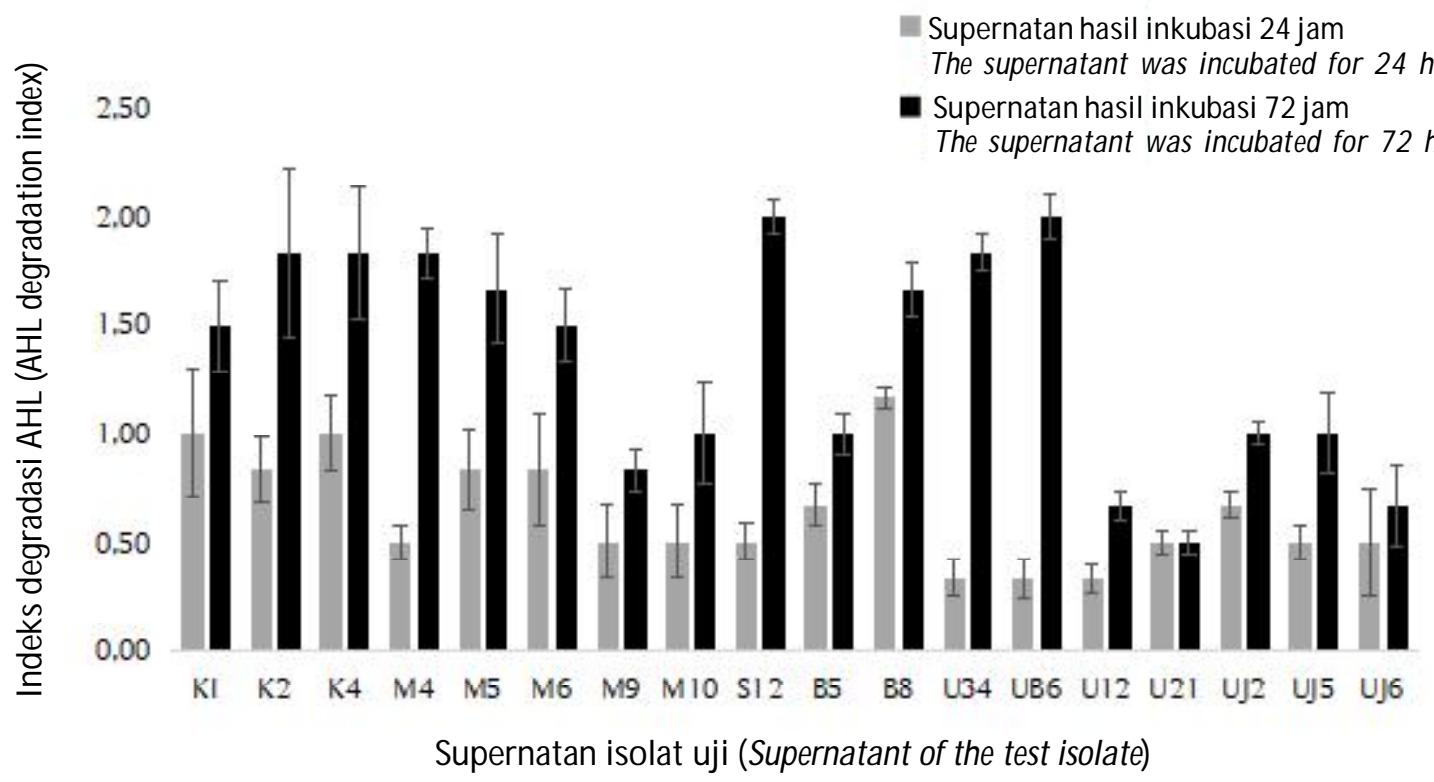

Gambar 2. Hasil seleksi bakteri AQS menggunakan C. violaceum berdasarkan nilai indeks degradasi AHL.

Figure 2 The screening results of anti-QS bacteria using C. violaceum based on AHL degradation index values.

tidak diikuti dengan penurunan pertumbuhan sel bakteri C. violaceum (Gambar 3). Penurunan kadar violacein tersebut terjadi karena terganggunya ekpresi gen penyandi violacein yang diduga disebabkan adanya degradasi AHL pada kultur C. violaceum oleh enzim pendegradasi AHL (Suryanti, 2019). Perubahan pigmentasi violacein $C$. violaceum yang dihasilkan pada media mudah diamati dan dapat dikuantifikasi secara fotometrik (Chaudhari et al., 2014).

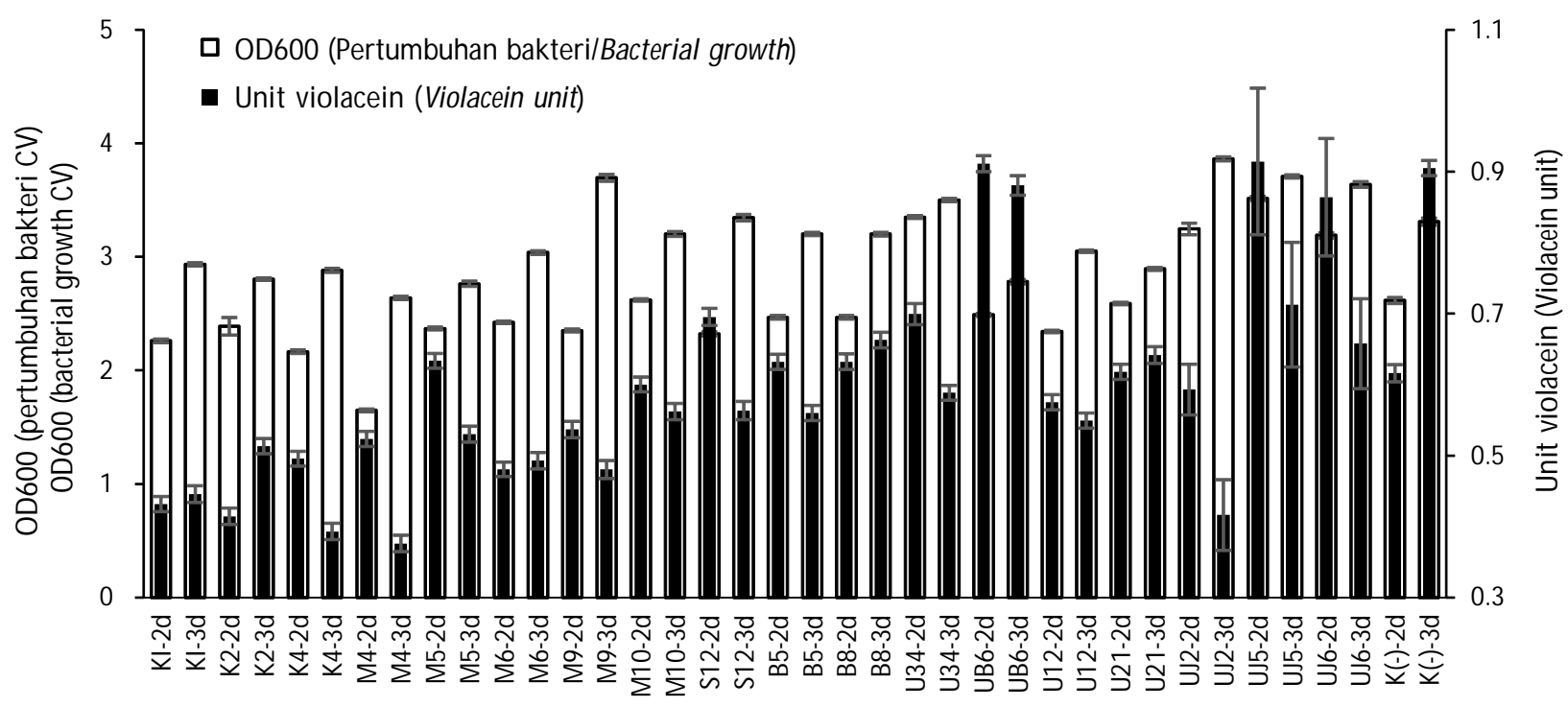

Perlakuan (Treatments)

Gambar 3. Hubungan kepadatan sel dan produksi violacein C. violaceum akibat perlakuan penambahan supernatan bakteri uji. Perlakuan penambahan supernatan bakteri AQS pada kultur C. violaceum yang diinkubasi selama 48 jam (2d) dan perlakuan selama 72 jam (3d).

Figure 3. Patterns of cell density and violacein production of $\mathbf{C}$. Violaceum after subjected to screenedbacteria supernatants. C. Violaceum were incubated for 48 hours (2d) and treatment for 72 hours (3d) post the addition of AQS bacterial supernatant. 


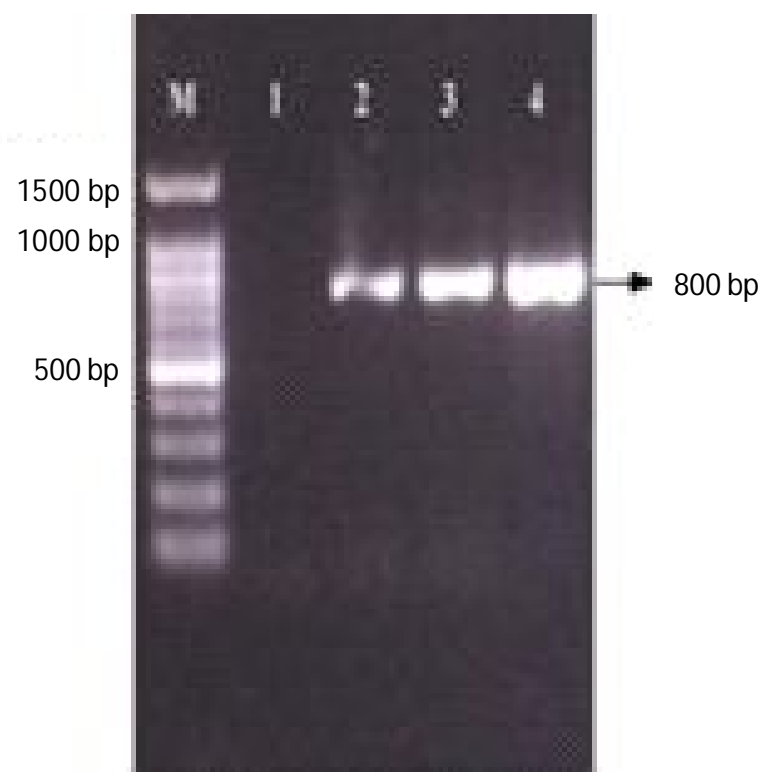

Gambar 4. Visualisasi DNA gen aiiA isolat uji. Lajur M: marker DNA 100 bp plus (Qiagen), lajur 1 kontrol negatif, lajur 2-4 sampel DNA isolat uji bertururt-turut K4, B5, dan S12.

Figure 4. Visualization of DNA aiiA genetest isolates. Lane M: DNA marker 100 bp plus (Qiagen); lane 1 negative control; lane 2-4 DNA samples from isolates $\mathrm{K} 4, \mathrm{~B} 5$, and $\mathrm{S} 12$.

Berdasarkan uji patogenitas secara in vitro pada agar darah didapatkan tiga isolat yang tidak menunjukkan aktivitas hemolisis yaitu B5, K4, dan S12. Konfirmasi keberadaan gen aiiA penyandi AHL laktonase menggunakan PCR terhadap ketiga isolat tersebut menghasilkan panjang basa 800 bp (Gambar 4). Selanjutnya dilakukan sekuensing dan analisis pohon filogenetik untuk mengidentifikasi jenis asam amino dan kekerabatannya dengan AHL laktonase yang dimiliki oleh bakteri lain pada GenBank (Gambar 5).

Hasil analisis sekuen gen aiiA menggunakan BLAST$X$ pada GenBank menunjukkan bahwa isolat B5 dan S12 memiliki kesamaan dengan $\mathrm{N}$-acyl homoserinelactonase yang dimiliki Bacillus cereus masing-masing 99,56\%(WP098582883.1) dan 99,17\% (WP098582883.1), sedangkan K4 memiliki kemiripan 99,55\%dengan multispesies Bacillus (W P071727701.1) (Gambar 5). Hasil konstruksi filogenetik dari sekuen penyusun asam amino AHL laktonase menunjukkan ketiganya berada pada kluster yang sama dengan $\mathrm{AHL}$ laktonase yang dimiliki kelompok Bacillus lainnya, dan berbeda kluster dengan AHL laktonase dari Vibrio alginolyticus sebagai out group (Gambar 5). Gen aiiA pada ketiga isolat tersebut tergolong ke dalam superfamili metallo-hydrolase-like metallo-ãlactamase. Metallo hydrolase adalah enzim hidrolitik yang melakukan berbagai fungsi biologis salah satunya
AHL laktonasese sebagai katalis hidrolisis pembukaan cincin lakton AHL (Chen et al., 2013).

Hasil pensejajaran sekuen gen 16S rRNA menggunakan BLAST-N menunjukkan isolat B5 memiliki kemiripan 99,93\% dengan Bacillus siamensis (MN176482.1), isolat K4 memiliki homologi 99,25\% dengan Bacillus cereus (KU377337.1) dan isolat S12 memiliki similaritas $99,93 \%$ dengan Bacillus amyloliquefaciens (NR117946.1). Analisis konstruksi filogenetik menunjukkan isolat B5 dan S12 termasuk dalam satu klaster dan tergolong kompleks spesies Bacillus subtilis (Fan et al., 2017), sedangkan K4 terbentuk dalam satu klaster B. cereus (Gambar 6).

Spesies Bacillus termasuk bakteri pertama yang dilaporkan mampu mendegradasi AHL dengan menghidrolisis cincin lakton oleh enzim laktonase yang dihasilkannya (Dong et al., 2002). Beberapa bakteri terutama Bacillus spp., memanfaatkan AHL-laktonase dalam quorum quenching untuk meningkatkan kekuatan kompetitif di tanah (Rasmussen \& Givskov, 2006). Penelitian dan pengaplikasian Bacillus sebagai pendegradasi AHL pada akuakutur mulai banyak dilakukan. Pemanfaatan Bacillus subtilis 1 x $10^{6} \mathrm{CFU}$ $\mathrm{mL}^{-1}$ dapat meningkatkan SR larva Penaeus monodon sebesar 65,56\%yang diinfeksi Vibrio harveyi (Yuniarti et al., 2015). Penambahan B. amyloliquefaciens $10^{3}$ CFU $\mathrm{mL}^{-1}$ mampu meningkatkan imunitas Litopenaeus 


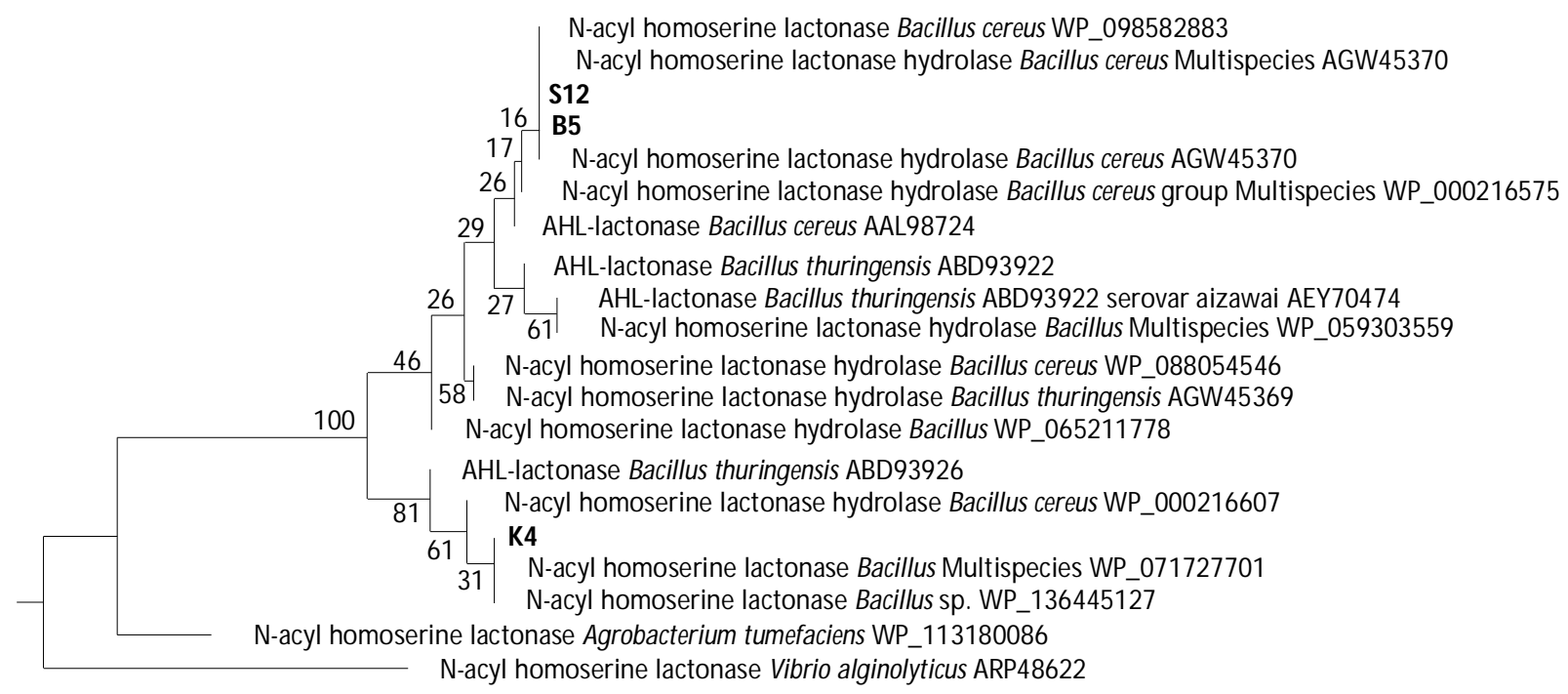

Gambar 5. Pohon filogenetik gen aiiA menggunakan metode Maximum Likelihood dengan bootstrap $1.000 \mathrm{X}$.

Figure 5. The phylogenetic tree of aiiA gene analyzed usingthe Maximum Likelihood method with bootstrap 1,000X.

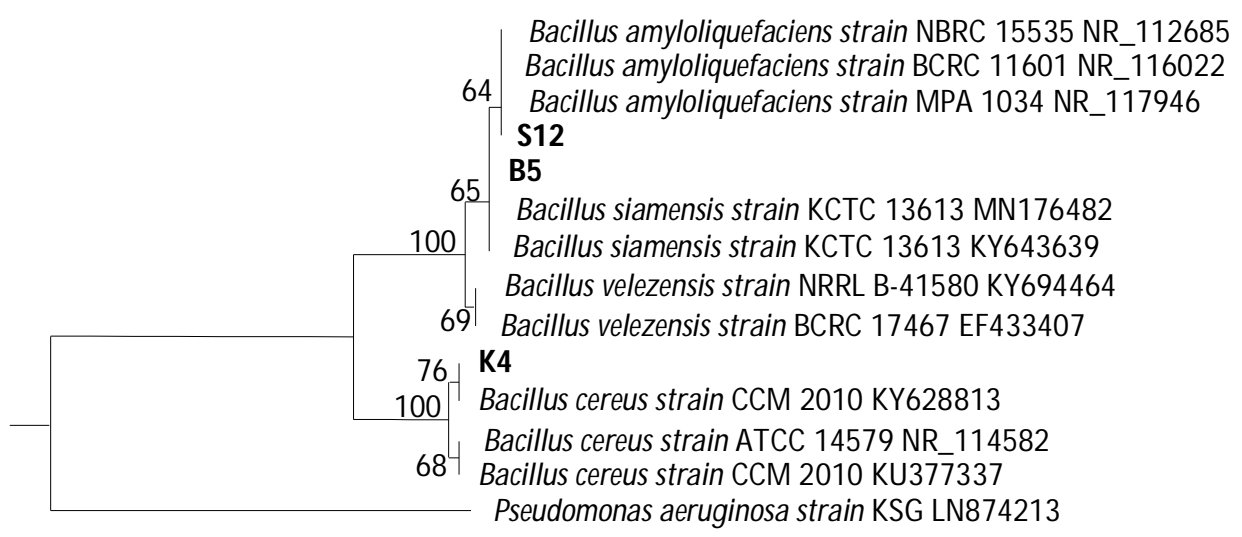

Gambar 6. Pohon filogenetik berdasarkan sekuen gen 16S rRNA menggunakan metode Maximum Likelihood dengan Bootstrap 1.000X.

Figure 6. Phylogenetic tree based on 165 rRNA gene sequences analyzed using the Maximum Likelihood method with Bootstrap 1,000X.

vannamei pada tambak sistem bioflok (Llario et al., 2020). Sebelumnya Novita et al. (2015) melaporkan pengaplikasian B. amyloliquefaciens melalui pakan ikan lele yang diinfeksi A. hydrophila mampu menghasilkan sintasan sebesar $81 \%$ Selanjutnya Wee et al. (2018) melaporkan Bacillus cereus berperan dalam menghambat patogentitas dari A. hydrophila pada juvenil $M$ acrobrachium rosenbergii. Sementara penambahan B. siamensis $10^{7} \mathrm{CFU} \mathrm{g}^{-1}$ pakan sebagai probiotik efektif meningkatkan kinerja pertumbuhan pada catfish (Meidong et al., 2016).
Hasil uji aktivitas antagonis bakteri AQS terhadap V. parahaemolyticus, isolat S12 dan B5 menunjukkan adanya zona hambat, sedangkan sekitar isolat $\mathrm{K} 4$ tidak terbentuk zona hambat (Gambar 7A). Hal ini mengindikasikan bahwa penghambatan patogenitas $\mathrm{V}$. parahaemoliticus oleh isolat K4 menggunakan mekanisme AQS, sedangkan isolat B5 dan S12 diduga berjalan dua proses secara bersama yaitu antibiosis dan anti quorum sensing yang didukung data kultur bersama bakteri V. parahaemolyticus dan bakteri AQS (Gambar 7B-D). 


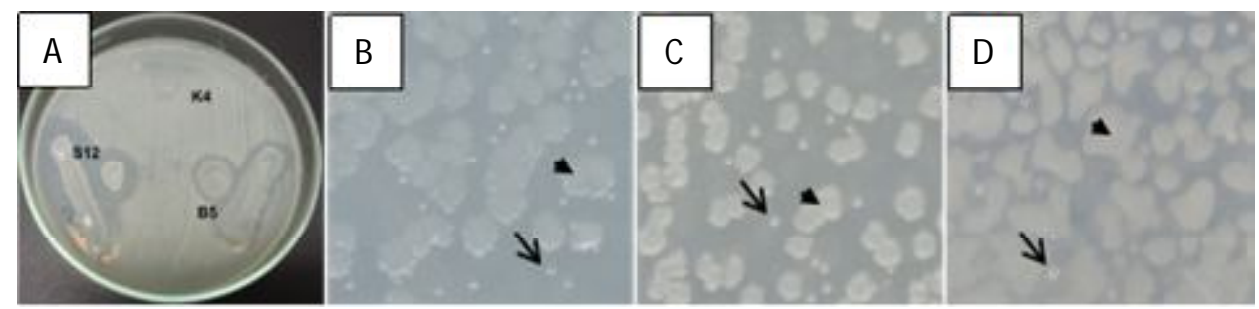

Gambar 7. Uji aktivitas antagonis bakteri AQS dan V. Parahaemolyticus pada media SWC(A) dan koloni bakteri hasil kultur bersama antara bakteri AQS (B5, K4, dan S12) dengan V. parahaemolyticus (B-D). Koloni V. parahaemolyticus (tanda panah), koloni bakteri AQS (kepala panah).

Figure 7. Antagonistic activity test of AQS bacteria to $\mathbf{V}$. parahaemolyticus on SWC media (A) and (B-D) growth of colonies of AQS bacteria (B5, K4, and S12) (short arrow) and $\mathbf{V}$. parahaemolyticus (long arrow) during coculture test.

Hasil uji kultur bersama selama 48 jam antara bakteri V. parahaemolyticus dan bakteri AQS. Jumlah total vibrio pada perlakuan bakteri B5, K4, dan S12 berturut-turut adalah $1,45 \times 10^{7} \mathrm{CFU} \mathrm{mL}^{-1} ; 3,74 \times 10^{7}$ CFU mL-1; dan $1,29 \times 10^{7} \mathrm{CFU} \mathrm{mL}^{-1}$, sedangkan pada kontrol positif $4 \times 10^{7} \mathrm{CFU} \mathrm{mL}^{-1}$ (Gambar 7B-D).

\section{KESIMPULAN}

Isolat bakteri AQS yang berhasil diisolasi dari tambak udang vaname teridentifikasi sebagai Bacillus siamensis (B5), Bacillus cereus (K4) dan Bacillus amyloliquefaciens (S12) yang terkonfirmasi memiliki AHL laktonase dan memiliki potensi sebagai agen biokontrol. Ketiga isolat tersebut perlu dilakukan uji Ianjutan secara in vivo untuk memastikan efektivitasnya dalam penghambatan patogenitas $\mathrm{V}$. parahemolyticus pada udang.

\section{UCAPAN TERIMA KASIH}

Ucapan terima kasih disampaikan kepada kepala Balai Uji Standar Karantina Ikan Pengendalian Mutu dan Keamanan Hasil Perikanan yang telah memfasilitasi laboratorium sebagai tempat penelitian ini dilaksanakan.

\section{DAFTAR ACUAN}

Chen, F., Gao, Y., Chen, X., Yu, Z., \& Li, Z. (2013). Quorum quenching enzymes and their application in degrading signal molecules to block quorum sensing-dependent infection. International Journal of Molecular Sciences, 14(9), 17477-17500.

Chaudhari, V., Gosai, H., Raval, S., \& Kothari, V. (2018). Effect of certain natural products and organic solvents on quorum sensing in Chromobacterium violaceum. Asian Pacific Journal of Tropical Medicine, 7(1), S204-S211.
Defoirdt, T., Boon, N., Bossier, P., \& Verstraete, W. (2004). Disruption of bacterial quorum sensing: an unexplored strategy to fight infections in aquaculture. Aquaculture, 240, 69-88.

Dong, Y.H., Gusti, A.R., Zhang, Q., Xu, J.L., \& Zhang, L.H. (2002). Identification of quorum-quenching $\mathrm{N}$-acyl homoserine lactonases from Bacillus species. Applied and Environmental Microbiology, 68, 1754-1759.

Fan, B., Blom, J., Klenk, H-P., \& Borriss, R. (2017). Bacillus amyloliquefaciens, Bacillus velezensis, and Bacillus siamensis form an "Operational Group B. amyloliquefaciens" within the $B$. subtilis species complex. Frointier in Microbiology, 8(22), 1-15.

Gram, L., Melchiorsen, J., Spanggaard, B., Huber, I., \& Nielsen, T.F. (1999). Inhibition of Vibrio anguillarumby Pseudomonas fluorescens $\mathrm{AH} 2$, a possible probiotic treatment of fish. Applied and Environmental Microbiology, 65, 969-973.

Llario, F., Romano, L.A., Rodilla, M.1., SebastiáFrasquet, M.T.1., Poersch, L.H. (2020). Application of Bacillus amyloliquefaciens as probiotic for Litopenaeus vannamei (Boone, 1931) cultivated in a bioflocsystem. Iranian Journal of Fisheries Sciences, 19(2), 904-920.

McClean, K.H., Winson, M.K., Fish, L., Taylor, A., Chhabra, S.R., Camara, M., Daykin, M., Lambr, J.H., \& Swift, S. (1997). Quorum sensing and Chromobacterium violaceum: Exploitation of violacein production and inhibition for the detection of Nacylhomoserine lactones. Microbiology, 143, 3703-3711.

Meidong, R., Doolgindachbaporn, S., Jamjan, W., Sakai, K., Tashiro, Y., Okugawa, Y., \& Tongpim. (2017). A novel probiotic Bacillus siamensis B44 
isolated from Thai pickled vegetables (Phak-dong) for potential use as a feed supplement in aquaculture. The Journal of General and Applied Microbiology.

Novita, H., Rusmana, I., Yuhana, M., \& Pasaribu, F.H. (2015). Potential of Bacillus sp., as a producer of AHL lactonase and its application as a probiotic for the prevention of MAS in catfish (Clarias gariepinus). Journal of Fisheries and Aquatic Science, 10(6), 464-476.

Rasmussen, T.B. \& Givskov, M. (2006). Quorum sensing inhibitors: A bargain of effects. Microbiology, 152, 895-904.

Sarjito, Haditomo, A.H.C., Desrina, Djunaedi, \& Prayitno, S.B. (2018). The diversity of vibrios associated with vibriosis in Pacific White Shrimp (Litopenaeus vannamei) from extensive shrimp pond in Kendal District, Indonesia. In 3rd International Conference on Tropical and Coastal Region Eco Development. (p. 012011.1-012011.7). Yogyakarta, Indonesia.

Suryanti, E. (2019). Potensi bakteri penghasil Ahl laktonase sebagai pengendali busuk lunak pada kentang oleh Dickeya Dadantii. Tesis. Bogor (ID): Institut Pertanian Bogor.

Tan, A.F. (2017). Isolation and characterisation of coral mucusbacilli with quorum quenching potential as abiocontrol agent for shrimp gut protection against
Early Mortality Syndrome (EMS). .Tesis. Swinburne University of Technology. Malaysia.

Tran, L., Nunan, L., Redman, R.M., Mohney, L.L., Pantoja, C.R., Fitzsimmons, K., \& Lightner, D.V. (2013). Determination of the infectious nature of the agent of acute hepatopancreatic necrosis syndrome affecting penaeid shrimp. Diseaseof Aquatic Organisms, 105(1), 45-55.

Umoro, A. (2016). Isolasi Bacillus sp. penghasil bacteriosin dan peningkatan aktivitasnya sebagai penghambat Vibrio harveyi. Tesis. Bogor (ID): Institut Pertanian Bogor.

Vinoj, G., Vaseeharan, B., Thomas, S., Spiers, A.J., \& Shanthi, S. (2014). Quorum-quenching activity of the AHL-lactonase from Bacillus licheniformis DAHB1 inhibits Vibrio biofilm formation in vitro and reduces shrimp intestinal colonisation and mortality. Marine Biotechnology, 16(6), 707-715.

Wee, W.C., Mok, C.H., Romano, N., Ebrahimi, M., \& Natrah, I. (2018). Dietary supplementation use of Bacillus cer eus as quorum sensing degrader and their effects on growth performance and response of Malaysian giant river prawn Macrobrachium rosenbergii juvenile towards Aeromonas hydrophila. Aquaculture Nutrition, 24(6), 1804-1812.

Yuniarti, A., Maftuch, Soemarno, \& Aulanni'am. (2015). In vitro and in vivo study of acyl homoserine lactone degrading Bacillus against Vibrio harveyi. International Journal of Biosciences, 6(2), 338-348. 